\title{
Issues at the Rural-Urban Fringe: Methods to Sustain Agricultural Land -- Use-Value Assessment ${ }^{1}$
}

Rodney L. Clouser²

\section{Introduction}

This fact sheet is one in a series intended to familiarize readers with land use issues at the rural-urban fringe. The next several fact sheets specifically address techniques used in various states, including Florida, to encourage the long-term stability of land in agricultural production. Many states use more than one technique in an attempt to prevent land from converting from agricultural to non-agricultural use. Future fact sheets will explicitly address techniques of Agricultural Zoning, Agricultural Districts, Fee Simple Purchase and Purchase of Development Rights, Transfer of Development Rights, Clustering of Development, and Conservation Easements.

\section{Definition}

Use-value assessment is a tax incentive program that shifts property tax burdens to other classes of property, since use-value assessment generally lowers the value of agricultural property relative to assessment at fair market value. Agricultural producers are taxed at the income earning potential of the land in agricultural production rather than at what a willing buyer would pay for the land. The term use-value assessment is often used interchangeably with the term "differential assessment." Eligibility criteria for use-value assessment in Florida are defined in Statute 193.461. In Florida, use-value assessment is often referred to as the state's "greenbelt" law. A summary of this statute can be found in EDIS publication FE550, Issues at the Rural-Urban Fringe: Florida State Laws Related to Land Use (http://edis.ifas.ufl.edu/FE550), or the entire statute can be accessed electronically from the state's web portal at http://www.MyFlorida.com.

\section{Background}

Maryland established the first statewide use-value assessment program in 1956. Florida was the second state to adopt a program in 1959. Between 1959 and 1969, another 19 states adopted some form of a statewide use-value assessment program.

Currently every state, except Michigan, has adopted some form of use-value assessment. Michigan has a form of differential assessment law which lowers property tax assessments but requires an agreement to keep the land in agricultural use that is not tied

1. This is EDIS document FE553, a publication of the Department of Food and Resource Economics, Florida Cooperative Extension Service, Institute of Food and Agricultural Sciences, University of Florida, Gainesville, FL. This document is one of a series entitled "Issues at the Rural Urban Fringe". Published July 2005. Please visit the EDIS website at http://edis.ifas.ufl.edu.

2. Rodney L. Clouser, Professor and Public Policy Specialist, Department of Food and Resource Economics, Florida Cooperative Extension Service, Institute of Food and Agricultural Sciences, University of Florida, Gainesville, FL.

The Institute of Food and Agricultural Sciences (IFAS) is an Equal Opportunity Institution authorized to provide research, educational information and other services only to individuals and institutions that function with non-discrimination with respect to race, creed, color, religion, age, disability, sex, sexual orientation, marital status, national origin, political opinions or affiliations. U.S. Department of Agriculture, Cooperative Extension Service, University of Florida, IFAS, Florida A. \& M. University Cooperative Extension Program, and Boards of County Commissioners Cooperating. Larry Arrington, Dean 
directly to the income-earning value of land in agricultural production. Because of its wide-scale adoption, use-value assessment is the most widely used technique in the United States today for maintaining land in agricultural production.

Motives for adopting and implementing use-value assessment programs are numerous. Some argue that agricultural and non-agricultural landowners are not treated equally. This represents an "equity" argument (equal treatment of equals). For example, agriculture landowners may receive a lower level of community services (police, fire, EMS, schools, roads, etc.) relative to the amount of land owned and property taxes paid than do their urban counterparts. Others argue that the appreciated value of land used in agriculture does not reflect an agricultural producer's ability to pay property taxes. They believe that reduced property taxes will encourage agricultural producers to remain in agriculture production. Some communities provide property tax concessions to agricultural landowners whose lands provide open space to discourage "leapfrog" development.

\section{Types of Programs}

Three primary types of use-value assessment programs have evolved in the United States: preferential assessment, deferred taxation, and restrictive agreements. Preferential assessment (taxation), which is used in Florida, is based on agricultural income-earning potential, with no penalties levied against the land or landowner if agricultural land is converted to non-agricultural uses. Other preferential assessment states include Arizona, Arkansas, Idaho, Iowa, Kansas, Louisiana, Missouri, Montana, New Mexico, North Dakota, Oklahoma, South Dakota, West Virginia, and Wyoming.

A second type of use-value assessment is deferred taxation. If agricultural land is converted to a non-agricultural use, a rollback tax is imposed on the property. The rollback tax is typically the difference between what was actually paid in taxes under use-value assessment and taxes that would have been paid if the land had not been assessed at use-value for a specified time period. In the United States, rollback provisions range from two to ten years. Twenty-six states have some form of rollback provision. The states with the longest rollback provisions (10 years) are Delaware, Hawaii, Indiana, and Oregon. States with the shortest rollback provisions (2 years) are New Jersey and Wisconsin. Southern states with rollback provisions are South Carolina (5 years); Tennessee ( 5 years for open space and 3 years for forest and agricultural production); Texas (5 years); Virginia (5 years); and Alabama, Georgia, and North Carolina (3 years each). In addition to the rollback tax some states may also charge interest on the difference in rollback taxes.

Another form of deferred taxation is percent penalty payback. A penalty is imposed at a fixed percentage (California, Maryland, New Hampshire, and Vermont) or on a sliding scale (Connecticut, Maine, and Rhode Island) of the market value of land in the year the land converts to non-agricultural use or is no longer eligible for use-value assessment. Fixed penalty payments range from 20 percent of market value in Vermont to 4 percent of market value in Maryland for land that is less than 20 acres in size. Sliding scale penalties range from 30 percent for forest land in Maine if land use changes in less than 10 years to no penalty in Connecticut and Rhode Island if land is used agriculturally for 10 and 15 years, respectively.

A third type of use-value assessment is restrictive agreement. Landowners who enter into an agreement for a specified number of years become eligible for preferential tax treatment. The restrictive agreement typically prohibits non-agricultural use of the land for a specified number of years. In California, the restrictive agreement period is 10 years. By signing the agreement, the landowner is eligible for a form of deferred taxation, but if the land use changes to non-agricultural, the landowner is subject to a fixed percentage penalty of 12.5 percent of the market value of the land.

Another program, circuit breaker tax credits, is often associated with use-value assessment, but it is not a true use-value program. Circuit breaker programs provide property tax relief as a direct credit against state income tax. Three states, Michigan, New York, and Wisconsin, have circuit breaker credit 
programs. In Michigan, property taxes above a certain household income level can be deducted dollar for dollar from the state income tax. In general, this form of tax relief provides an outcome similar to use-value assessment (reduction in taxes paid), but it does not provide for taxation of land on the income generating capability of the property like use-value assessment does.

\section{Policy Considerations}

Use-value assessment programs have proven to be politically acceptable, with 49 states in the United States having some form of the program. Deferred taxation programs seem to be the most popular option within states. These programs allow a community to recapture some of the tax reductions provided to agricultural landowners if land use changes to non-agricultural use. However, agricultural producer support for deferred taxation programs is often linked to the length of the rollback period and the amount of interest charged. In states using preferential assessment of agricultural property taxes, there may be little or no interest in amending state laws to provide for rollback provisions. This happens because preferential assessment of land provides the landowner flexibility to change land use from agricultural to non-agricultural with no financial penalties.

Use-value assessment programs result in a tax shift from agricultural property to non-agricultural property. Although this tax shift typically results in small property tax increases to non-agricultural property owners, it may result in substantial tax savings to agricultural landowners. In general, tax savings to agriculture producers are greater near urban or urbanizing areas because the differential between the market value and use value tends to be larger. At the same time, increases in property taxes to other property classes, due to tax shifts, tend to be smaller because there are larger numbers of property owners and property values among which to spread the tax shift. Case studies have indicated that use-value assessment may result in keeping land in agricultural production for short periods of time or from idling the land from production, but history documents that these type programs have not prevented the long-term conversion of agricultural land. Even in the short-run, use-value assessment does not assure that large contiguous blocks of agricultural land will remain in production or support agricultural business suppliers.

There is an unfounded belief that use-value assessment always results in reduced taxable value of agricultural land. This is not true.

Intensively-produced, high-valued commodities may result in higher assessments than do less intensive and less valuable crops. The same could be true in areas with low potential for land development and low housing demand. Use-value assessment could result in higher values for tax purposes for land left idle, for open space, or for land owned by governmental bodies which is often tax exempt. As an example, in a small rural county in south Florida, citrus land is assessed in the $\$ 3500$ range, sod-producing land is assessed just under $\$ 1500$, and unimproved pasture is assessed at less than $\$ 100$ on a per acre basis under use-value assessment. A large vacant parcel of land, in a rural area in the same county, with poor soil conditions (wet) and not managed in any active manner, has an assessment value in the neighborhood of $\$ 2500$ per acre. So, even with use-value assessment, the citrus land would be assessed at a higher value than would vacant land assessed at fair market value.

Finally, significant concern has been expressed by individuals concerning land speculators and developers. These individuals purchase land for development purposes while being eligible to receive use-value assessment until the property is fully developed. Agricultural property may not be in an economically productive use for many years while waiting to be developed, yet the developer is eligible for lowered taxes. Criteria in Florida to determine "bona fide agricultural" use include the length of time the land has been so utilized; continuous use; purchase price paid; size as it relates to specific agricultural use; documented evidence effort has been made to care sufficiently and adequately for the land in accordance with accepted commercial agricultural practices; proof the land is under lease, including length, terms, and conditions of the lease; and current zoning as it relates to commercial agriculture. Economic viability is not explicitly a criterion. This has caused many to question whether 
use-value assessment is an effective method to keep land in production and whether the program is an effective way to achieve tax equity related to services received and income generated by commercial agricultural producers.

\section{References}

American Farmland Trust. 1998. Differential Assessment and Circuit Breaker Tax Programs. Farmland Information Center, American Farmland Trust, Washington, D.C.

Clouser, Rodney L. 2005. Issues at the Rural-Urban Fringe: Florida State Laws Related to Land Use. Electronic Data Information Source (EDIS) FE550. Department of Food and Resource Economics, University of Florida, Gainesville, FL. http://edis.ifas.ufl.edu/FE550.

Clouser, Rodney L., and David Mulkey. 1987. Maintaining Land for Agriculture. FRE 28. Department of Food and Resource Economics, University of Florida, Gainesville, FL.

England, Richard W., and Robert D. Mohr. 2004. Land Development and Current Use Assessement. Whittemore School of Business and Economics, University of New Hampshire, Durham, NH.

Olson, Allen H. Website visited May 2005. Taxation of Agricultural Lands: Parts I, II, and III. http://www.allenholson.com/ TaxationofAgriculturalLands.jsp. 